\title{
Analyzing Tobin's Q Ratio of Banking Industry of Bangladesh: A Comprehensive Guideline for Investors
}

\author{
Md. Rostam Ali ${ }^{1}$, Md. Shahed Mahmud ${ }^{2 *}$, Reshma Pervin Lima ${ }^{3}$ \\ ${ }^{1}$ Assistant Professor, Department of Business Administration, Mawlana Bhashani Science and Technology University, Santosh, Tangail- \\ 1902, BANGLADESH \\ ${ }^{2,3}$ Lecturer, Department of Business Administration, Mawlana Bhashani Science and Technology University, Santosh, Tangail-1902, \\ BANGLADESH \\ *E-mail for correspondence: shahed.m.mbstu@gmail.com
}

\begin{abstract}
Due to the share market crash in 2010-2011, the investors have lost confidence regarding the share market till now. Therefore, this study is an endeavor to giveaway to rethink about the share market of Bangladesh and to increase the confidence of the investors. For that, Tobin's $Q$ ratio used to analyze the share market in this study. Tobin's $Q$ represents the ratio of the market value of a firm's share capital to the replacement cost of the firm's share capital. Tobin's $Q$ is greater than one means stock is overvalued. Tobin's $Q$ is less than one means stock is undervalued. Again, Tobin's $Q$ is equal to one means stock is fairly valued. The study found that, the value of Tobin's $Q$ of the all sampling banks is gradually decreasing means moving the value of the stock from overvalued to undervalue. The value of Tobin's Q of the all sampling banks is less than one in the year 2014 except Dutch Bangla Bank Limited (DBBL). The average value of Tobin's $Q$ of the banking industry is also decreasing and the average value of Tobin's $Q$ of the banking industry is less than one in the year 2014. Thus, the average stock value of the banking industry is moving from overvalued to undervalue gradually. Again, the value of Tobin's Q of all sampling banks fell down drastically from the year 2010 to the year 2011 as share market has been crashed in those years. As a result, the average value of Tobin's $Q$ of banking industry also fell down drastically from the year 2010 to the year 2011. Therefore, the value of the share slopes down drastically from the year 2010 to the year 2011.
\end{abstract}

Keywords: Tobin's Q (ratio), Banking Industry of Bangladesh, Investor/s, Stock Market/Share market

\section{INTRODUCTION}

In the stock market the shares of publicly held companies are issued and traded. It is also known as the equity market. The stock market plays a very important role and treated as one of the most important factors for the economy of a country (Investopedia, February 2016). It gives the companies to collect the long term capital in consideration of giving investors a part of ownership in the company. The fund is an inevitable part of economic development. By the help of stock market small funds are accumulated into large ones. In stock market, anyone can invest in different company's share for gaining profit, which can help for the development of a country. But making a profitin the share market is not an easy task. If anyone wants to be a profitable investor in share market, s/he should be careful and very much aware about the factors related to it.

The stock market of Bangladesh has been crashed in 2010-2011. Actually stock market crash means an unexpected decreasing of share prices in the stock marketvery rapidly. The stock market of Bangladesh faced the 'Bull Run' before the market crash has been occurred. In 2007 the military backed caretaker government, took the power by declaring a state of emergency due to political unrest of Bangladesh. During that period Foreign Direct Investment (FDI) decreased and the investment in real sectors also decreased but the foreign remittance increased. As investment in real sectors decreased, the investors invested their fund in the stock market as an attractive source of alternatives. Moreover, the new investors having no prior knowledge, follow the footstep of unaware investors for gaining more profit from the market and invested in some wrong share. According to CPD (2011) internet based trading operation, opening branches of brokerage houses across the country, easy access to the market information, arranging a countrywide share Mela (fair) are the factors for increasing investment and attract new investors in the share market. 
In 2009-2010, due to the lack of business opportunity and opportunity to invest in real sectors the banks and other financial institutions of Bangladesh had a lot of excess liquidity. Theses financial institutions invested the excess liquidity in the share market to minimize the cost of bearing excess liquidity. Again, the general people took loan from these banks and other financial institutions invested in the share market. This made a huge influx of liquidity in the share market. Bangladesh Bank adopted accommodative monetary policy and increased the money supply to support investmentto continue the growth $7-8 \%$ per year. Besides, the government permitted whitening of black money through tax breaks. As a result the big portion of this excess liquidity had gone into the stock market, but there were very few shares in the market to adopt these huge liquidity. Moreover, supplies of new securities through IPOs were not enough to chase huge capital of too many investors in the market. The prices of the share of $\mathrm{Z}$ Category Companies and small companies increased rapidly. These factors affected the market in the 'Bull Run' and this 'Bull Run' condition of the market accelerated the share market crash in 2010-2011 and the investors lost confidence regarding the share market till now. Therefore, this study is an endeavour to giveaway to rethink about the share market and to increase the confidence level of the investors.

After the independence, the banking industry in Bangladesh started its journey with 6 nationalized commercialized banks, 2 state owned specialized banks and 3 foreign banks. In the 1980's banking industry achieved a significant expansion with the entrance of private banks. Right now, there are 56 scheduled banks in Bangladesh which operate under full control and supervision of Bangladesh Bank. Financial sector of Bangladesh is dominated by banks and the share of this sector in the Gross Domestic Product (GDP) is $2.87 \%$ for the fiscal year 2014-15 (Bangladesh Economic Review 2015). Furthermore, during the last ten years the total asset of the banking sector has grown rapidly which is the sign of the remarkable contribution of banking sector in the development of the country.

Tobin Q links up between goods and services market and share market, which have a multiple impacts in macroeconomics. It is a ratio between a physical asset's market value and its replacement value. It was introduced in 1968 by James Tobin and William Brainard. James Tobin, a Nobel Prize winner in economics and a professor at Yale University, developed the ratio after hypothesizing that companies should be "worth" what they cost to replace. In Economics theory of investment behavior where 'Tobin's Q' represents the ratio of the market value of a firm's outstanding shares (share capital) to the replacement cost of the firm's physical assets (replacement cost of the share capital). It states that if 'Tobin's Q' is greater than one means that the firm is worth more than the cost of its assets In this case, additional investment in the firm would make sense because the profits generated would exceed the cost of a firm's assets. If 'Tobin's $Q$ ' is less than one means it costs more to replace a firm's assets than the firm is worth, the firm would be better off selling its assets instead of trying to put them to use. The ideal state is where 'Tobin's $Q$ is approximately equal to one denoting that the firm is in equilibrium. It is also called general equilibrium theory or $Q$ theory. Tobin's $Q$ is sometimes written as "Tobin's-q", "Tobin's Q" or simply Q. It is also called Tobin's Quotient, since the Q stands for Quotient. Sometimes, people call it the "BrainardTobin Q. (Stephen R Bond.; Jason G Cummins. 2004).

\section{Objectives}

The main objective of the study is to analyze the Tobin's $\mathrm{Q}$ of Banking Industry of Bangladesh from the investors' perspective and the specific objectives of the study are:

- To evaluate the Banking Industry on the basis of market value and its stated book value.

- To measure the performance of the Banking Industry from the investors' point of view.

- To contribute some guidelines to the investors to invest in the Banking Industry in Bangladesh.

\section{LITERATURE REVIEW}

Richard Blundell et. al. (1990) conducted a study on "Investment and Tobin's Q Evidence from company panel data." The aim of this paper has been to investigate the importance of Tobin's Q in the determination of investment decisions at the company level. Where, $\mathrm{Q}$ was found to be a significant determinant of investment, its coefficient was small. Since the numerator of $Q$ relates to the stock market value of the company, it appears that the investment rate is relatively unresponsive, at least in the short run, to variations in equity values. Indeed, the short-run elasticity of the gross investment rate to the equity market value indicates that a $10 \%$ rise in the equity market value would be associated with an immediate rise in the investment rate of only $2.5 \%$.

Lang Lariy H.P. et. al. (1993) in their study, showed that Tobin's $\mathrm{q}$ and firm diversification are negatively related. They further show that diversified firms have lower q's than equivalent portfolios of specialized firms. In their sample, firms that increase their number of segments have lower q's than firms that keep their number of segment constant. They fail to find evidence supportive of the view that diversification provides firms with a valuable intangible asset.

Kee H. Chung and Stephen W. Pruitt (1994) have developed in their study on a simple approximating of Tobin's q. They proved the approximate $\mathrm{q}$ value with those obtained via Lindenberg and Ross (1981) more theoretically correct model indicate that at least $96.6 \%$ of the variability of Tobin's $q$ is explained by the approximate $q$. 
Anderson Catapan et al (2012) have conducted a study on "The relationship between profitability indicators and Tobin's Q: A focus on Brazilian electric sector." On that article they developed a research that compares the relations between the indicators of profitability and $Q$ de Tobin to know if there are any significant statistical differences between EBITDA/ Assets, EBITDA/PL, ROA, ROE and Tobin's $\mathrm{q}$ in Brazilian Electric Companies. They found that the profitability indicators have a strong influence on the value of Tobin's $q$, in the context of the Brazilian electric sector.

Joseph Wolfe, Antonio Carlos and Aidar Sauaia (2003) have conducted a study on "THE TOBIN q AS A COMPANY PERFORMANCE INDICATOR." This paper investigates the use of Tobin's $\mathrm{q}$ as a more-meaningful way to judge the comparative performance of firms in business games. The results were inconclusive and indicate further investigation would be useful.

Behrooz Nabavand and Javad Rezaei (2015) have conducted a study on "Review between Tobin's $Q$ with performance Evaluation Scale Based Accounting and Marketing Information in Accepted Companies in Tehran Stock Exchange." The research investigated the relationship between Tobin's Q and performance evaluation criteria based on accounting and market information in companies listed on the Tehran Stock Exchange in a 5-year period. The results obtained from this study show that there is a significant relationship between the Tobin's Q ratio and criteria of "earnings per share", "market price of shares to their book value of equity", and "return on equity" during the 5-year period of this research as well as there is no significant relationship between the Tobin's $Q$ ratio and ratios of "price to earnings per share" and "return on total assets".

Based on the above analysis of literature no works have been performed to analyze the Tobin's $Q$ ratio for the banking industry of Bangladesh. Therefore, an initiative has been taken to address the issue. Furthermore, give some room for the real investors to rethink about the share market of Bangladesh.

\section{Methodology}

For this study, seven banks of the banking sector in Bangladesh have been selected purposively as the market price of the shares of those banks for the the sampling years are available. The sample banks are Prime Bank Limited (PBL), Dhaka Bank Limited (DBL), Dutch Bangla Bank Limited (DBBL), AB Bank Limited (ABL), Al-Arafah Islami Bank Limited (AAIBL), Eastern Bank Limited (EBL) and Mercantile Bank Limited (MBL). Secondary data from the annual reports of the sample banks for the years 2010 to 2014 used to complete this work. The end-of-year number of shares outstanding and end-of-year share price from Dhaka Stock Exchange (DSE) and annual reports have been used to calculate the market value of equity.
Trend analysis of Tobin's $Q$ has been done by considering the objectives of the study. The Tobin's $Q$ ratio measures the market value of a company compared to the replacement value of the firm's assets.

Tobin's $Q=\frac{\text { Market Value }}{\text { Total Asset Value }}$

$$
=\frac{\text { Equity Market Value }+ \text { Liabilities Market Value }}{\text { Equity Book Value }+ \text { Liabilities Book Value }}
$$

It is also a common practice to assume equivalence of the liabilities market and book value, yielding:

So,

Tobin's $Q=\frac{\text { Equity Market Value + Liabilities Book Value }}{\text { Equity Book Value + Liabilities Book Value }}$

Again,

Tobin's

$=\frac{\text { Equity Market Value }+ \text { Liabilities Book Value }}{\text { Equity Book Value + Liabilities Book Value }} \approx \frac{\text { Equity Market Value }}{\text { Equity Book Value }}$

As the study is considering the Tobin's $Q$ on the investors' point of view, in this study it is assumed that, the Tobin's $Q$ equal to the equity market value divided byequity book value. Therefore,

Tobin's $\mathbf{Q}=\frac{\text { Equity Market Value }}{\text { Equity Book Value }}$

Where,

- $\quad$ Market Value of Equity $=$ Market price per Share $\times$ Number of Share Outstanding.

- Book Value of Equity = Total Assets - Total Liabilities.

\section{Discriminate Zone}

Tobin's $Q>1$ means the stock is overvalued. To an investor this value implies that the market value is higher than the company's stated book value. In other words, the market is selling the companys' assets higher than its stated book value. So, its stock is more expensive than the costs of its assets.

Tobin's $\mathrm{Q}<1$ means the stock is undervalued. To an investor this value implies that the market value is lower than the company's stated book value. In other words, the market is selling the company's assets less than its stated book value. So, the market value is below the cost of its assets.

Tobin's $\mathrm{Q}=1$ means the stock is fairly valued. So, market value reflected solely the recorded assets of a company.

\section{ANALYSIS AND DISCUSSION}

In this study Tobin's $Q$ represents the ratio of the market value of a firm share capital to the replacement cost of the firm's share capital. The numerator of the ratio is the market valuation means the market value of a firm's outstanding shares. The denominator of the ratio is the replacement or reproduction cost means the book value of the equity. 
From the table- 1 it is found that the value of Tobin's Q of the all banks is gradually decreasing. The value of Tobin's $\mathrm{Q}$ of AB Bank Limited (ABL) has a decreasing trend from 4.12 to below $01(0.88)$ over the last three years. The value of Tobin's $Q$ of DBL, EBL and MBL has been decreasing bellow one (01) from the last two years. The value of Tobin's Q of PBL and AAIBL has been decreasing below one (01) from the year 2014. Though the value of Tobin's Q of DBBL is decreasing gradually, the value of Tobin's $Q$ of this bank is greater than one (01). The value of Tobin's $Q$ of all sample banks fell drastically from the year 2010 to the year 2011 as share market has been crashed in those years. As a result, the average value of Tobin's $Q$ of banking industry also fell drastically from the year 2010 to the year 2011.

Stock is overvalued when Tobin's $Q$ greater than one $(\mathrm{Q}>1)$ means that the market value is higher than the company's stated book value. The stock is undervalued when Tobin's $Q$ less than one $(Q<1)$ means the market value is lower than the company's stated book value. Again, Stock is fairly valued when Tobin's $Q$ equal to one $(Q=1)$ means the market value reflected solely the recorded assets of a company.

Table-1: Calculation of the Tobin's Q Ratio

\begin{tabular}{|c|c|c|c|c|c|c|c|c|}
\hline Name & Years & $\begin{array}{l}\text { Mkt. value } \\
\text { per share }\end{array}$ & $\begin{array}{l}\text { No. of } \\
\text { Share }\end{array}$ & $\begin{array}{c}\text { Equity } \\
\text { Mkt. Value }\end{array}$ & Total Asset & Total Liability & $\begin{array}{c}\text { Net worth or } \\
\text { Equity Book Value }\end{array}$ & $\begin{array}{l}\text { Tobin's } \\
\text { Q ratio }\end{array}$ \\
\hline \multirow{5}{*}{$\begin{array}{l}\text { Prime Bank } \\
\text { Limited (PBL) }\end{array}$} & 2010 & 94.45 & $577,636,710$ & $54,557,787,260$ & $154,342,057,902$ & $137,433,920,891$ & $16,908,137,011$ & 3.23 \\
\hline & 2011 & 44.50 & $779,809,558$ & $34,701,525,331$ & $199,950,493,482$ & $180,811,768,551$ & $19,138,724,931$ & 1.81 \\
\hline & 2012 & 37.00 & $935,771,469$ & $34,623,544,353$ & $236,833,005,579$ & $216,045,966,674$ & $20,787,038,905$ & 1.67 \\
\hline & 2013 & 25.90 & $1,029,348,616$ & $26,660,129,154$ & $243,868,804,824$ & $220,839,187,716$ & $23,029,617,108$ & 1.16 \\
\hline & 2014 & 19.60 & $1,029,348,616$ & $20,175,232,874$ & $254,912,200,069$ & $230,451,488,089$ & $24,460,711,980$ & 0.82 \\
\hline \multirow{5}{*}{$\begin{array}{l}\text { Dhaka Bank } \\
\text { Limited (DBL) }\end{array}$} & 2010 & 76.30 & $265,959,780$ & $20,292,731,214$ & $90,139,480,260$ & $83,559,750,872$ & $6,579,729,388$ & 3.08 \\
\hline & 2011 & 44.50 & $359,045,703$ & $15,977,533,784$ & $104,725,650,056$ & $95,508,895,248$ & $9,216,754,808$ & 1.73 \\
\hline & 2012 & 24.80 & $466,759,413$ & $11,575,633,442$ & $133,616,109,915$ & $123,829,798,738$ & $9,786,311,177$ & 1.18 \\
\hline & 2013 & 18.80 & $541,440,919$ & $10,179,089,277$ & $144,408,630,421$ & $132,521,721,525$ & $11,886,908,896$ & 0.86 \\
\hline & 2014 & 18.30 & $568,512,964$ & $10,403,787,241$ & $158,747,543,561$ & $146,002,029,936$ & $12,745,513,625$ & 0.82 \\
\hline \multirow{5}{*}{$\begin{array}{l}\text { Dutch Bangla } \\
\text { Bank Limited } \\
\text { (DBBL) }\end{array}$} & 2010 & 229.30 & $200,000,000$ & $45,860,000,000$ & $123,267,035,863$ & $114,327,407,960$ & $8,939,627,903$ & 5.13 \\
\hline & 2011 & 161.30 & $200,000,000$ & $32,260,000,000$ & $122,853,846,136$ & $113,912,510,542$ & $8,941,335,594$ & 3.61 \\
\hline & 2012 & 114.30 & $200,000,000$ & $22,860,000,000$ & $185,537,386,894$ & $172,895,666,310$ & $12,641,720,584$ & 1.81 \\
\hline & 2013 & & $200,000,000$ & $20,940,000,000$ & $185,013,464,445$ & $172,385,644,122$ & & 1.66 \\
\hline & 2014 & 105.80 & $200,000,000$ & $21,160,000,000$ & $214,498,513,261$ & $200,012,781,192$ & $14,485,732,069$ & 1.46 \\
\hline \multirow{5}{*}{$\begin{array}{l}\text { AB Bank } \\
\text { Limited (ABL) }\end{array}$} & 2010 & 158.05 & $368,611,390$ & $58,259,030,190$ & $133,706,824,450$ & $119,559,947,093$ & $14,146,877,357$ & 4.12 \\
\hline & 2011 & 68.30 & $368,611,390$ & $25,176,157,937$ & $154,404,751,243$ & $139,389,318,058$ & $15,015,433,185$ & 1.68 \\
\hline & 2012 & & $442,333,668$ & $14,906,644,612$ & $175,517,312,012$ & $159,315,040,863$ & 149 & 0.92 \\
\hline & 2013 & 26.20 & $497,625,376$ & $13,037,784,851$ & $208,005,543,738$ & $191,065,494,672$ & $16,940,049,066$ & 0.77 \\
\hline & 2014 & 29.90 & $532,459,152$ & $15,920,528,645$ & $254,668,156,050$ & $236,511,042,476$ & $18,157,113,574$ & 0.88 \\
\hline \multirow{5}{*}{$\begin{array}{l}\text { Al-Arafah } \\
\text { Islami Bank } \\
\text { Limited } \\
\text { (AAIBL) }\end{array}$} & 2010 & 66.88 & $467,727,936$ & $31,281,644,360$ & $4,104,967,444$ & & $4,039,144,612$ & 7.74 \\
\hline & 2011 & 37.80 & $589,337,199$ & $22,276,946,122$ & $103,518,725,256$ & $93,925,455,697$ & $9,593,269,559$ & 2.32 \\
\hline & 2012 & 24.29 & $713,098,010$ & $17,321,150,663$ & $146,334,812,318$ & $133,909,068,598$ & $12,425,743,720$ & 1.39 \\
\hline & 2013 & 19.10 & $834,324,671$ & $15,935,601,216$ & $170,935,600,597$ & $156,457,541,133$ & $14,478,059,464$ & 1.10 \\
\hline & 2014 & 14.90 & $946,958,503$ & $14,109,681,695$ & $206,548,713,972$ & $189,950,591,177$ & $16,598,122,795$ & 0.85 \\
\hline \multirow{5}{*}{$\begin{array}{l}\text { Eastern Bank } \\
\text { Limited (EBL) }\end{array}$} & 2010 & 129.40 & $292,081,140$ & $37,795,299,516$ & $82,530,978,439$ & $70,273,534,050$ & $12,257,444,389$ & 3.08 \\
\hline & 2011 & 65.80 & $452,725,767$ & $29,789,355,469$ & $117,585,778,252$ & $102,992,575,660$ & $14,593,202,592$ & 2.04 \\
\hline & 2012 & 31.70 & $611,179,785$ & $19,374,399,185$ & $147,044,438,547$ & $129,794,892,351$ & $17,249,546,196$ & 1.12 \\
\hline & 2013 & 29.10 & $611,179,785$ & $17,785,331,744$ & $57,881,633,856$ & $39,431,135,681$ & $18,450,498,175$ & 0.96 \\
\hline & 2014 & 27.20 & $611,179,785$ & $16,624,090,152$ & $172,124,130,885$ & $152,037,279,481$ & $20,086,851,404$ & 0.83 \\
\hline \multirow{5}{*}{$\begin{array}{l}\text { Mercantile } \\
\text { Bank Limited } \\
(\mathrm{MBL})\end{array}$} & 2010 & 58.05 & $407,220,000$ & $23,639,121,000$ & $87,140,109,470$ & $79,954,424,207$ & $7,185,685,263$ & 3.29 \\
\hline & 2011 & 34.80 & $496,810,000$ & $17,288,988,000$ & $116,655,283,665$ & $106,924,395,401$ & $9,730,888,264$ & 1.78 \\
\hline & 2012 & 19.10 & $611,080,000$ & $11,671,628,000$ & $154,147,704,702$ & $143,163,700,929$ & $10,984,003,773$ & 1.06 \\
\hline & 2013 & 16.70 & $659,960,000$ & $11,021,332,000$ & $145,102,377,756$ & $132,469,941,047$ & $12,632,436,709$ & 0.87 \\
\hline & 2014 & 13.70 & $739,160,000$ & $10,126,492,000$ & $169,100,738,129$ & $155,538,660,063$ & $13,562,078,066$ & 0.75 \\
\hline
\end{tabular}

Source: Annual Reports of the Sampling Banks of Different years

From the Table- 2 and Figure- 1 it is found that the value of Tobin's $Q$ ratio of the all the sample banks is gradually decreasing, which indicates, moving the value of the stock from overvalued to undervalue. Though the value of the stock of AB Bank Limited is overvalued in the years 2010 and 2011, the value of the stock is undervalued in the years 2012, 2013 and 2014. The value of the stocks of DBL, EBL and MBL are overvalued in the years 2010, 2011 and 2012, 
the value of the stocks are undervalued in the years 2013 and 2014. The value of the stocks of PBL and AAIB are overvalued in the years 2010, 2011, 2012 and 2013, the value of the stocks are undervalued in the year 2014. Though the value of the stock of DBBL is decreasing gradually, the value of the stock of this bank is overvalued.

Table-2: Trend Analysis of Tobin's Q Ratio of Banking Industry for the Year-2010 to 2014

\begin{tabular}{|c|c|c|c|c|c|c|c|c|c|c|c|c|c|c|c|}
\hline \multirow{3}{*}{ Names } & \multirow{2}{*}{\multicolumn{5}{|c|}{ Q-Ratio $=\frac{\text { Equity Market Value }}{\text { Equity Book Value }}$}} & \multicolumn{10}{|c|}{ Q-Benchmark } \\
\hline & & & & & & \multicolumn{2}{|c|}{ Year-2010 } & \multicolumn{2}{|c|}{ Year-2011 } & \multicolumn{2}{|c|}{ Year-2012 } & \multicolumn{2}{|c|}{ Year-2013 } & \multicolumn{2}{|c|}{ Year-2014 } \\
\hline & 2010 & 2011 & 2012 & 2013 & 2014 & $Q>1$ & $Q<1$ & $Q>1$ & $Q<1$ & $Q>1$ & $Q<1$ & $Q>1$ & $Q<1$ & $Q>1$ & $Q<1$ \\
\hline PBL & 3.23 & 1.81 & 1.67 & 1.16 & 0.82 & $\sqrt{ }$ & & $\sqrt{ }$ & & $\sqrt{ }$ & & $\sqrt{ }$ & & & $\sqrt{ }$ \\
\hline DB & 3.08 & 1.73 & 1.18 & 0.86 & 0.82 & $\sqrt{ }$ & & $\sqrt{ }$ & & $\sqrt{ }$ & & & $\sqrt{ }$ & & $\sqrt{ }$ \\
\hline DBBL & 5.13 & 3.61 & 1.81 & 1.66 & 1.46 & $\sqrt{ }$ & & $\sqrt{ }$ & & $\sqrt{ }$ & & $\sqrt{ }$ & & $\sqrt{ }$ & \\
\hline $\mathrm{AB}$ & 4.12 & 1.68 & 0.92 & 0.77 & 0.88 & $\sqrt{ }$ & & $\sqrt{ }$ & & & $\sqrt{ }$ & & $\sqrt{ }$ & & $\sqrt{ }$ \\
\hline AAIB & 7.74 & 2.32 & 1.39 & 1.1 & 0.85 & $\sqrt{ }$ & & $\sqrt{ }$ & & $\sqrt{ }$ & & $\sqrt{ }$ & & & $\sqrt{ }$ \\
\hline EBL & 3.08 & 2.04 & 1.12 & 0.96 & 0.83 & $\sqrt{ }$ & & $\sqrt{ }$ & & $\sqrt{ }$ & & & $\sqrt{ }$ & & $\sqrt{ }$ \\
\hline MBL & 3.29 & 1.78 & 1.06 & 0.87 & 0.75 & $\sqrt{ }$ & & $\sqrt{ }$ & & $\sqrt{ }$ & & & $\sqrt{ }$ & & $\sqrt{ }$ \\
\hline Average & 4.24 & 2.14 & 1.31 & 1.05 & 0.92 & $\sqrt{ }$ & & $\sqrt{ }$ & & $\sqrt{ }$ & & $\sqrt{ }$ & & & $\sqrt{ }$ \\
\hline
\end{tabular}

Trend of the Tobin's Q of banking Industry

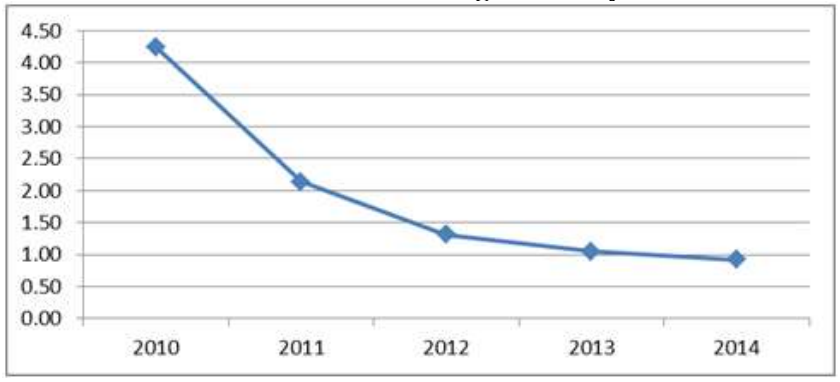

Again, the average value of Tobin's $Q$ of the banking industry is also decreasing and average value of Tobin's $\mathrm{Q}$ of the banking industry is lower than one in the year 2014. So, the average stock value of the banking industry is moving from overvalued to undervalue gradually. Though the average stock value of the banking industry is overvalued in the years 2010, 2011, 2012 and 2013, the average stock value of the banking industry is undervalued in the year 2014.

The value of Tobin's Q of all sampling banks fell drastically from the year 2010 to the year 2011 as share market has been crashed in those years. As a result, the average value of Tobin's Q of banking industry also fell drastically from the year 2010 to the year 2011. So, the value of the share fell drastically from the year 2010 to the year 2011.

Due to the share market collapse in 2010-2011, the investors have lost confidence regarding share market till now. The study found that the value of Tobin's $Q$ of the all banks is gradually decreasing means moving the value of the stock from overvalued to undervalue. The value of Tobin's $Q$ ratio of the all banks is less than one in the year 2014 except DBBL. To an investor this value implies that the market value is lower than the company's stated book value. In other words, the market is selling the company's assets less than its stated book value. So, the market value is below the cost of its assets.

\section{RECOMMENDATIONS}

By analyzing the Tobin's $Q$ ratio for the banking sector of Bangladesh, the following recommendation can be drawn, upon which investor/s can rethink regarding their investment plan and decision-

- The Tobin's Q ratios almost of the all sampling banks are less than one (01) in the sampling year 2014 and the industry Tobin's Q ratio is also less than one (01) in that particular year (2014) indicate that the banking industry was undervalued. To an investor this value implies that the market value is lower than the company's stated book value. In other words, the market is selling the company's assets less than its stated book value. So, the market value is below the cost of its assets. Therefore, the investor can invest in the banking industry.

- As the Tobin's Q ratio of DBBL is greater than one in the sampling years means the stock is overvalued. To an investor this value implies that the market value is higher than the company's stated book value. In other words, the market is selling you the company's assets higher than its stated book value. So, its stock is more expensive than the costs of its assets. Hence, if any investor wants to sell any share from the sampling banks, then they should sell the share of DBBL.

- Before investing in the share market the investors should consider P/E Ratio of the share, Price of last few days of that share, intrinsic value of the share and last few years dividend declarations of the company, the overall market condition and trend besides Tobin's Q ratio, as the stock market is too much volatile especially in Bangladesh.

- Investors must have prior knowledge about different terms and conditions and other related information such as government policies and decision, respective authority's decision and policies, market trend, regulator's plan regarding market stability, different index regarding share market.

- $\quad$ Time is one of the important factors while making an investment decision in share market. Investors should have the mentality to invest for the medium-term or 
long-term basis. Day trading should have to be avoided while making an investment decision.

- To be a profitable investor in the share market the investor must have practical knowledge and experience about share market. In this case, the investor can attend in the different seminars arranged by BSEC, DSE, and CSE for gathering information and knowledge.

- The investor should invest in those shares of those companies which gives regular dividend, have low $\mathrm{P} / \mathrm{E}$ ratio, sound paid-up capital, growing sector, top management or higher authorities' leadership, knowledge and skill and the forecasting capacity, etc. Again, the investor should also consider the different on-going projects of this particular company before an investment decision.

- If the market is volatile then holding the share for more profit is not wise as the market volatility increases the risk. But investors should be more calculative, conscious and aware of the situation of market volatility rather than be panicked.

- Investors should be more conscious about the rumor regarding share market as sometimes the investors are misguided in the share market with wrong information. If investor gets any information regarding share market, that should have to be properly evaluated and the authenticity should be properly verified. The investors should accept only that information which is written and evaluated legal evidence.

- $\quad$ Finally the Government should take proper initiatives to increase the confidence level of investors about share market. The coordination among Bangladesh Bank, Ministry of Finance, BSEC, DSE, CSE and Brokerage House Association should be properly maintained. The person/s behind the share market scam of 2010-11 should be found out and legal actions should be taken quickly. Otherwise, the investors' confidence level gradually falls down in the long run.

\section{CONCLUSION}

This study is an endeavor to giveaway to rethink about the share market to the investors. In the study, Tobin's $Q$ represents the ratio of the market value of a firm's share capital to the replacement cost of the firm's share capital. The value of Tobin's $\mathrm{Q}$ of the banking industry is decreasing. So, the stock value of the banking industry is moving from overvalued to undervalue gradually. Therefore, the investor can invest in the banking industry as the share of this industry in undervalued. But before investing in the share market the investors should consider $\mathrm{P} / \mathrm{E}$ Ratio of the share, Price of the last few days of the share,
Intrinsic value of the share and last few years dividend declarations of the company besides Tobin's Q ratio. Investors must have proper knowledge about different terms and conditions and other related information such as government policies, government decision, respective authority's decision and policies, different index regarding share market. Besides this the Government should take proper initiatives to upsurge the confidence level of investors regarding share market. The coordination among Bangladesh Bank, Ministry of Finance, BSEC, DSE, CSE and Brokerage House Association should be maintained. The punishment should be given to those persons who are related to the share market crash in 2010-2011.

\section{REFERENCES}

Blundell, Richard. et. al. (1990) “Investment and Tobin's Q Evidence from company panel data". Journal of Econometrics 51 (1992), North-Holland. pp. 233-257.

Bond, Stephen R.; Cummins, Jason G. (2004). "Uncertainty and Investment: An Empirical Investigation Using Data on Analysts' Profits Forecasts". FEDS Working Paper No. 2004-20.

Brainard, William C.; James, Tobin. (1968). "Pitfalls in Financial Model Building." American Economic Review. pp.99-122.

Catapan, Anderson et. al. (2012) "The relationship between profitability indicators and tobin's Q: A focus on Brazilian electric sector." Universal Journal of Marketing and Business Research. Vol. 1(4). pp. 104-111

Chung, Kee H.; Pruitt, Stephen W. (1994) “A Simple Approximation of Tobin's q." Financial Management. Vol. 23, No. 3.pp 70-74

CPD, 2011. Independent Review of Bangladesh's Development (IRBD). Restriped from <http://www.cpd.org.bd/downloads/IRBD\%20FY11_First\% 20Reading.pdf $>$ [Accessed on April 1, 2016].

Finance Division, Bangladesh Economic Review 2015 (Dhaka: Ministry of Finance, Government of the People Republic of Bangladesh, 20015), p.19

Lang L.H.P.; Stulz R.M. (1993) “Tobin's Q, Corporate Diversification and Firm Performance." National Bureau of Economic Research 1050 Massachusetts Avenue Cambridge, MA 02138

Nabavand, Behrooz.; Javad Rezaei. (2015) “Review between Tobin's $Q$ with performance Evaluation Scale Based Accounting and Marketing Information in Accepted Companies in Tehran Stock Exchange." Journal of Applied Environmental and Biological Sciences. Vol. 4. pp. 138-146

Web: <http://www.investopedia.com/terms/q/qratio.asp> Accessed on $09 / 10 / 2015$

Web: <http://www.investopedia.com/terms/s/stockmarket.asp? layout=infini\&v=5A\&orig=1\&adtest=5A $>$ Accessed on 09/02/2016

Wolfe, Joseph.; Carlos, Antonio.; Aidar Sauaia. (2003) “The Tobin Q as a Company Performance Indicator." Developments in Business Simulation and Experiential Learning.Vol. 30 pp 155-159

$--0--$

Indexed Archive Links

OCLC WorldCat: http://goo.gl/vhQzla

Google Scholar: https://goo.gl/t23FeQ

abcGATE: http://goo.gl/E6WdgA

BASE: http://goo.gl/sEd0SZ 